\title{
Evaluation of some properties of an opaque porcelain fired simultaneously with the body porcelain
}

\author{
William J. O'Brien, PhD, ${ }^{a}$ Kenneth M. Boenke, ${ }^{b}$ and \\ Carole L. Groh, BS, MBA \\ School of Dentistry, The University of Michigan, Ann Arbor, Mich.
}

\begin{abstract}
Recently, a porcelain-fused-to-metal opaque porcelain was introduced that does not require a separate firing before application of the hody porcelain. The objective of this study was to determine the properties of this new opaque porcelain and its ability to bond to metal. The properties studied included flexural strength, linear firing shrinkage, coefficient of thermal expansion, powder particle size, and ability to bond to body porcelain and dental alloys. Sintering of this opaque porcelain was complete when fired at $1760^{\circ} \mathrm{F}\left(960^{\circ} \mathrm{C}\right)$ with a linear firing shrinkage of $13.1 \% \pm 0.2 \%$. No boundary between the opaque and body porcelains could be found with a scanning electron microscope after firing at $1760^{\circ} \mathrm{F}\left(960^{\circ} \mathrm{C}\right)$. The mean flexural strengths were $99 \pm 7$ and $101 \pm 8 \mathrm{MPa}$ respectively, for this opaque porcelain and a conventional opaque porcelain, and were not significantly different as assessed with Student's $t$-test $(p=0.548)$. The coefficient of thermal expansion for this opaque porcelain was $13.3 \pm 0.2 \times 10^{-6} /{ }^{\circ} \mathrm{C}$. Particle size analysis showed a $63 \%$ increase in the particles below $5 \mu \mathrm{m}$ for this opaque porcelain and bonding to two alloys was adequate as indicated by its cohesive failure. Simultaneous firing of this special opaque porcelain and body porcelain produced satisfactory sintering, strength, and bonding to metal. (J PROSTHET DeNT 1994;72:414-9.)
\end{abstract}

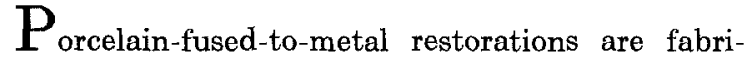
cated from at least three porcelains to form an esthetic layered structure. An opaque porcelain is applied to the metal to mask the metal oxide color. After the opaque porcelain is fired, subsequent layers of body (gingival) and incisal porcelain are added for a minimum of three firings. Because each firing and cooling takes 20 to 25 minutes, the process is time-consuming and labor intensive. An opaque porcelain is now available that does not require a separate firing before application of the body porcelain (No-Bake Opaque, Excelco International Inc., Deerfield Beach, Fla.). The technician applies the No-Bake Opaque porcelain to the metal and then builds up the body porcelain layer and fires them both together. Although this procedure only saves approximately 20 to 25 minutes, the savings for the millions of these crowns made annually would be considerable. This study determined the properties of a new opaque

Presented at the International Associalion for Dental Research, Boston, Mass., March 1992.

Study supported by grant No. DE-09296 from the National Institute of Dental Research, National Institutes of Health, Bethesda, Md.

aProfessor, Department of Biologic and Materials Sciences.

${ }^{b}$ Research Assistant, Department of Biologic and Materials Sciences.

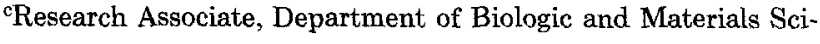
ences.

Copyright (ङ) 1994 by The Editorial Council of THE JOURNAL OF Prosthetic Dentistry

$0022-3913 / 94 / \$ 3.00+0 . \quad \mathbf{1 0} / \mathbf{1} / \mathbf{5 7 7 6 7}$ porcelain that docs not require a separate firing and its ability to bond to metal.

\section{MATERIAL AND METHODS}

No-Bake Opaque porcelain (shade A3, lot No. 1791) was used throughout this study. A standard opaque porcelain (Brush-O-Paque, DB-A4, lot No. 8015050, Excelco International Inc.) was used when comparisons were made. The body porcelain used was Gingival DG-A4 porcelain (lot No. 8012030, Excelco International Inc.). The two alloys used were Jelenko Olympia (JF Jelenko, Armonk, N.Y.) and Will-Ceram W1 (Williams Dental, Amherst, N.Y.) alloys.

\section{Flexural strength}

The flexural strength in three-point bending was determined $^{1}$ for six specimens. The bars were prepared by pressing the powder into a steel mold $(25 \mathrm{~mm} \times 5 \mathrm{~mm} \times 2$ $\mathrm{mm}$ ) with a load of $500 \mathrm{~kg}$ and firing to $1800^{\circ} \mathrm{F}\left(982^{\circ} \mathrm{F}\right)$. A tensile testing apparatus was used to fracture the samples (Model HTC, John Chatillon \& Sons, New York, N.Y.). The flexural strength of five conventional opaque porcelain samples (Brush-O-Paque, Excelco International Inc.) was also measured for comparison. A statistical evaluation of the means of these two porcelains was performed according to Student's $t$-test with two-tailed $p$ value.

\section{Sintering}

The degree of densification caused by sintering was determined by the change in linear firing shrinkage as a function of temperature and by scanning electron microscope (SEM) analysis (1000B, AmRay Inc,, Bedford, Mass.). 
Rectangulas bars were prepared by pressing the powder into a steel mold ( $25 \mathrm{~mm} \times 5 \mathrm{~mm} \times 2 \mathrm{~mm}$ ) with a load of $500 \mathrm{~kg}$. Three bars were fired at each of the following temperatures: $1360^{\circ} \mathrm{F}\left(738^{\circ} \mathrm{C}\right), 1460^{\circ} \mathrm{F}\left(793^{\circ} \mathrm{C}\right), 1560^{\circ} \mathrm{F}$ $\left(849^{\circ} \mathrm{C}\right), 1660^{\circ} \mathrm{F}\left(904^{\circ} \mathrm{C}\right)$, and $1760^{\circ} \mathrm{F}\left(960^{\circ} \mathrm{C}\right)$. The linear firing shrinkage was estimated by measuring the change in dimensions of the tablets produced by sintering. The change in linear fring shrinkage $(L S)$ was calculated by use of the following formula

$$
\mathrm{IS}=\frac{\mathrm{Lm}-\mathrm{Ls}}{\mathrm{Lm}} \times 100
$$

where $L m$ is the length of the mold cavity, and $L s$ is the length of the sample after firing. ${ }^{1}$ A one-way analysis of variance was computed with respect to the effect that firing temperature had on linear shrinkage. Paired comparisons were run wich simultaneous confidence intervals.

\section{Bonding}

Bonding to body porcelain. The bonding between the No-Bake Opaque and body (Excelco International Inc.) porcelains was assessed on layered tablets prepared in a stee mold $(9.5 \mathrm{~mm}$ in diameter $)$. A dual layered tablet was made by pressing moistened body porcelain in the mold with a load of $500 \mathrm{~kg}$ to produce a $2 \mathrm{~mm}$ thick layer; the plunger was removed, and moistened No-Bake Opaque porcelain was added to the mold. The plunger was placed in the mold, and the No-Bake Opaque porcelain was pressed on top of the body porcelain with a load of $500 \mathrm{~kg}$ to produce a $2 \mathrm{~mm}$ thick laver. Firing was carried out at $1460^{\circ} \mathrm{F}\left(793^{\circ} \mathrm{C}\right), 1560^{\circ}$ $\mathrm{F}\left(849^{\circ} \mathrm{C}\right), 1660^{\circ} \mathrm{F}\left(904^{\circ} \mathrm{C}\right)$, and $1760^{\circ} \mathrm{F}\left(960^{\circ} \mathrm{C}\right)$, followed by fracture in diametral tension to obtain a fracture perpendicular to the interface. This fractured surface was examined with an SEM to qualitatively observe the nature of the interface between the two porcelains and determine if any voids or porosity were present or whether the bond was continuous along this interface.

Bonding to metals. Alloy bonding samples were prepared by applying a thin layer of No-Bake Opaque porcelain to six degassed flags ( $16 \mathrm{~mm} \times 13 \mathrm{~mm} \times 1 \mathrm{~mm}$ ) of two commercial alloys. Unfired tablets $(9.5 \mathrm{~mm}$ in diameter and $4 \mathrm{~mm}$ thick) of the body porcelain were then placed on top of the No-Bake Opaque porcelain, and the specimens were fired to $1800^{\circ} \mathrm{F}\left(982^{\circ} \mathrm{C}\right)$. The cooled samples were tested for bonding with the use of a drop ball tester (Model 170041, American Optical Corp, Southbridge, Mass.). The porcelain disks were fractured by a falling steel ball, and the interfacial fractures were examined with an SEM and classified according to the fracture surfaces formed. ${ }^{2}$

\section{Coeficient ot thermal expansion}

The coefficient of thermal expansion of No-Bake Opaque porcelain was measured on four rectangular bars $(6 \mathrm{~mm} \times 6$ mm $\times 51 \mathrm{~mm}$ ) with a single-push dilatometer (Model TDA-H1-MP6, Harrop Laboratories, Columbus, Ohio). The dilatometer was calibrated on the cooling curve with

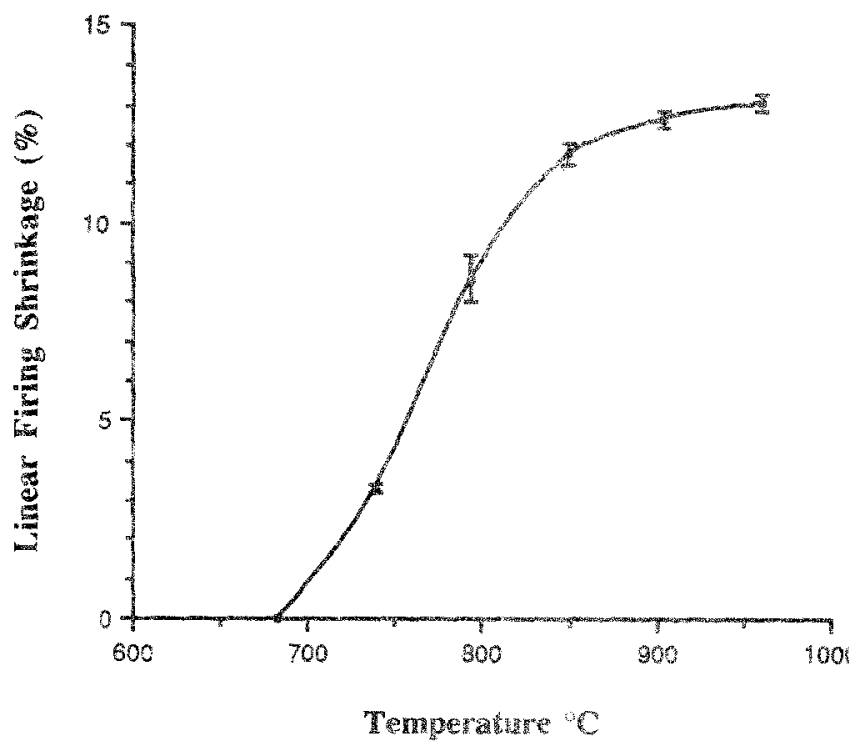

Fig. 1. Linear firing shrinkage as function of tenperature for No-Bake Opaque porcelain.

an alumina standard. The coeffoient, of themal expansion value was determined with the cooling curve between $25^{\circ}$ and $500^{\circ} \mathrm{C}$ with a heating and cooling rate of $4^{\circ} \mathrm{C} / \mathrm{min}$. The coefficient of thermal expansion of the lody porcelain was also measured for comparison. A gtatisuical evaluation of the means of these two porcelains was performed according to Student's $t$-test with two-waled $p$ walue.

\section{Particle size analysis}

The particle size distribution of No Hake Opaque porcelain was determined by measuring the sedimentation rate of the powder in a solution of $0.05 \%$ tetrasodium py. rophosphate (Huron Valley Steel, rtentwon, Mich.) in die tilled water by means of a particle size andyzer (Sedigraph 5000D, Micromeritics Instrument Corp, Norcross, Ga.) The particie size distribution of a comventional opaque porcelain was also measured for comparison. The Kolmogorov-Smirnov two-sample two-taled test with 70 intervals was used to test for statistical differences between the distributions.

\section{RESULTS}

\section{Flexural strength}

The flexural strengths were $99 \pm 7 \mathrm{WPa}$ for No-Bake Opaque and $101 \pm 8 \mathrm{MPa}$ for the conventional opaque porcelain and were not statistically different according to Student's $t$-test $(t$ statistic $=-0.623, p=0.548)$. These are excellent results for an opacue porcelain, well above the International Organization for Standardization (XSO) requirement ${ }^{1}$ of $55 \mathrm{MPa}$.

\section{Sintering}

The relationship between hiring tempergture and hear firing shrinkage is shown in Fig. $l$ and Tableg I and $I$. An 

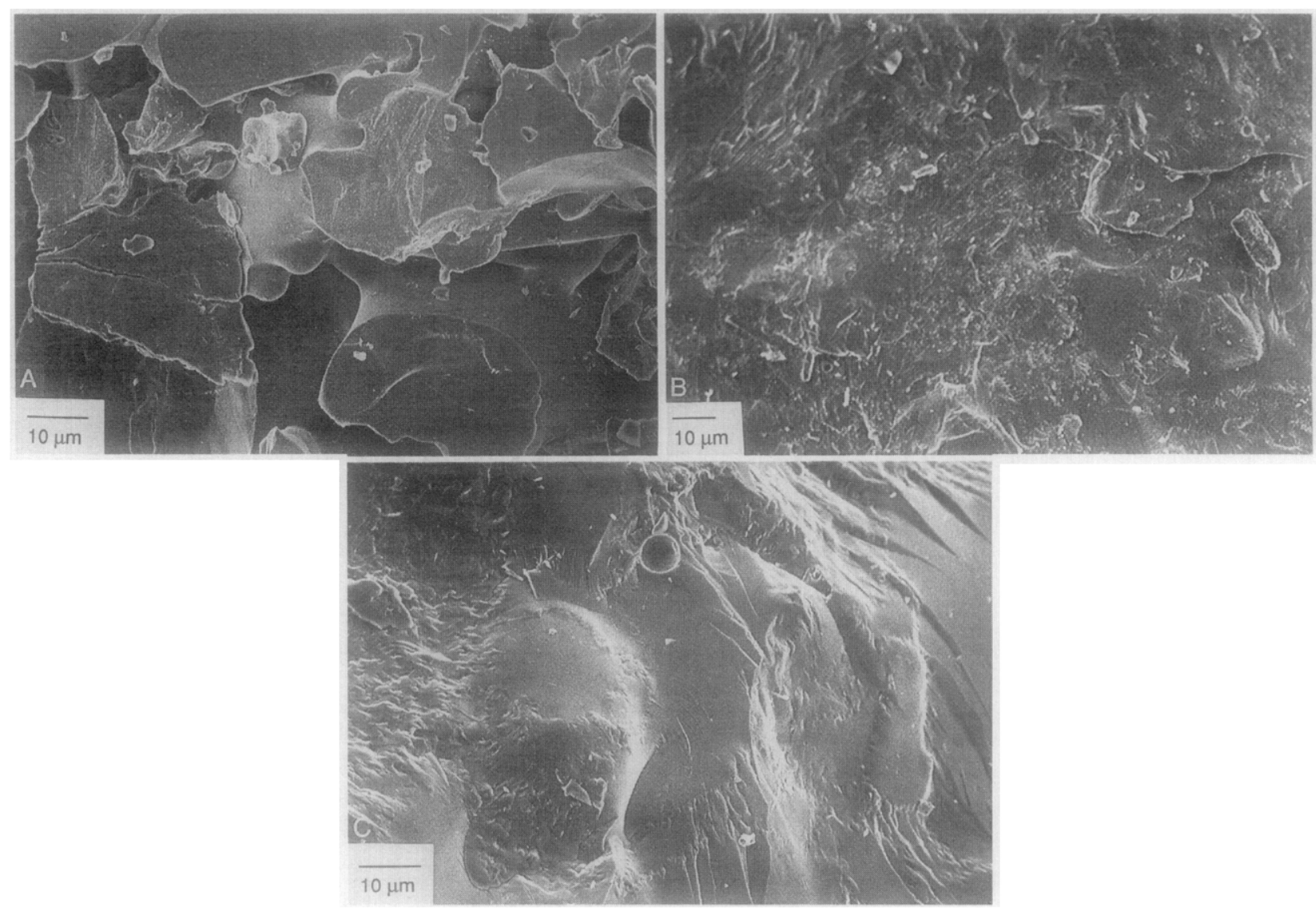

Fig. 2. SEM photomicrographs of No-Bake Opaque porcelain fracture sintered at (A) $1560^{\circ} \mathrm{F}\left(849^{\circ} \mathrm{C}\right),\left(\right.$ B) $1660^{\circ} \mathrm{F}\left(904^{\circ} \mathrm{C}\right)$, and (C) $1760^{\circ} \mathrm{F}\left(960^{\circ} \mathrm{C}\right)$.

Table I. Relationship between firing temperature and linear shrinkage for No-Bake Opaque porcelain

\begin{tabular}{|c|c|c|}
\hline \multirow{2}{*}{$\underset{\text { Firing }}{\text { temperature }\left({ }^{\circ} \mathrm{F}\right)}$} & \multicolumn{2}{|c|}{ Linear firing shrinkage (\%) } \\
\hline & Mean & SD \\
\hline 1360 & 3.3 & 0.08 \\
\hline 1460 & 8.6 & 0.56 \\
\hline 1560 & 11.8 & 0.31 \\
\hline 1660 & 12.7 & 0.15 \\
\hline 1760 & 13.1 & 0.20 \\
\hline
\end{tabular}

Groups joined by vertical lines are not significantly different with Scheffe F-test at the $95 \%$ confidence level

Table II. Statistical analysis

\begin{tabular}{lrccrc}
\hline & \multicolumn{3}{c}{ One-way analysis of variance } \\
\cline { 2 - 4 } Source & $d f$ & $\begin{array}{c}\text { Sum of } \\
\text { squares }\end{array}$ & $\begin{array}{c}\text { Mean } \\
\text { square }\end{array}$ & $\begin{array}{c}\text { F- } \\
\text { test }\end{array}$ & $\begin{array}{c}\boldsymbol{p} \\
\text { Value }\end{array}$ \\
\cline { 2 - 4 } Between groups & 4 & 154.5 & 38.6 & 369.7 & 0.0001 \\
Within groups & 9 & 0.941 & 0.105 & & \\
Total & 13 & 155.5 & & \\
\hline
\end{tabular}

analysis of variance showed that a significant effect of temperature occurred on linear firing shrinkage $(p<0.0001)$. No significant difference occurred in linear shrinkage between the temperatures of $1560^{\circ} \mathrm{F}\left(849^{\circ} \mathrm{C}\right)$ and $1660^{\circ} \mathrm{F}\left(904^{\circ} \mathrm{C}\right)$ or between $1660^{\circ} \mathrm{F}\left(904^{\circ} \mathrm{C}\right)$ and $1760^{\circ} \mathrm{F}\left(960^{\circ} \mathrm{C}\right)$. The linear firing shrinkages at the latter two temperatures were $12.7 \% \pm 0.2 \%$ and $13.1 \% \pm 0.2 \%$, respectively, which is well within the ISO limit ${ }^{1}$ of $16 \%$ max. Fig. 2 illustrates representative SEM photomicrographs of the No-Bake Opaque porcelain fired at $1560^{\circ} \mathrm{F}$ $\left(849^{\circ} \mathrm{C}\right), 1660^{\circ} \mathrm{F}\left(904^{\circ} \mathrm{C}\right)$, and $1760^{\circ} \mathrm{F}\left(960^{\circ} \mathrm{C}\right)$. The NoBake Opaque porcelain appears to be fully sintered at $1760^{\circ} \mathrm{F}\left(960^{\circ} \mathrm{C}\right.$ ) (Fig. 2, C).

\section{Bonding}

Fig. 3 shows representative SEM photomicrographs of No-Bake Opaque/body porcelain interfaces produced by firing at $1560^{\circ} \mathrm{F}\left(849^{\circ} \mathrm{C}\right), 1660^{\circ} \mathrm{F}\left(904^{\circ} \mathrm{C}\right)$, and $1760^{\circ} \mathrm{F}$ $\left(960^{\circ} \mathrm{C}\right)$. These photomicrographs show that the bonding of the No-Bake Opaque porcelain to the body porcelain was nearly complete at $1660^{\circ} \mathrm{F}\left(904^{\circ} \mathrm{C}\right)$ and was completed by $1760^{\circ} \mathrm{F}\left(960^{\circ} \mathrm{C}\right.$ ) (Fig. 3, C).

Photomicrographs of the fractured samples of No-Bake Opaque porcelain and tablets of body porcelain fired on 


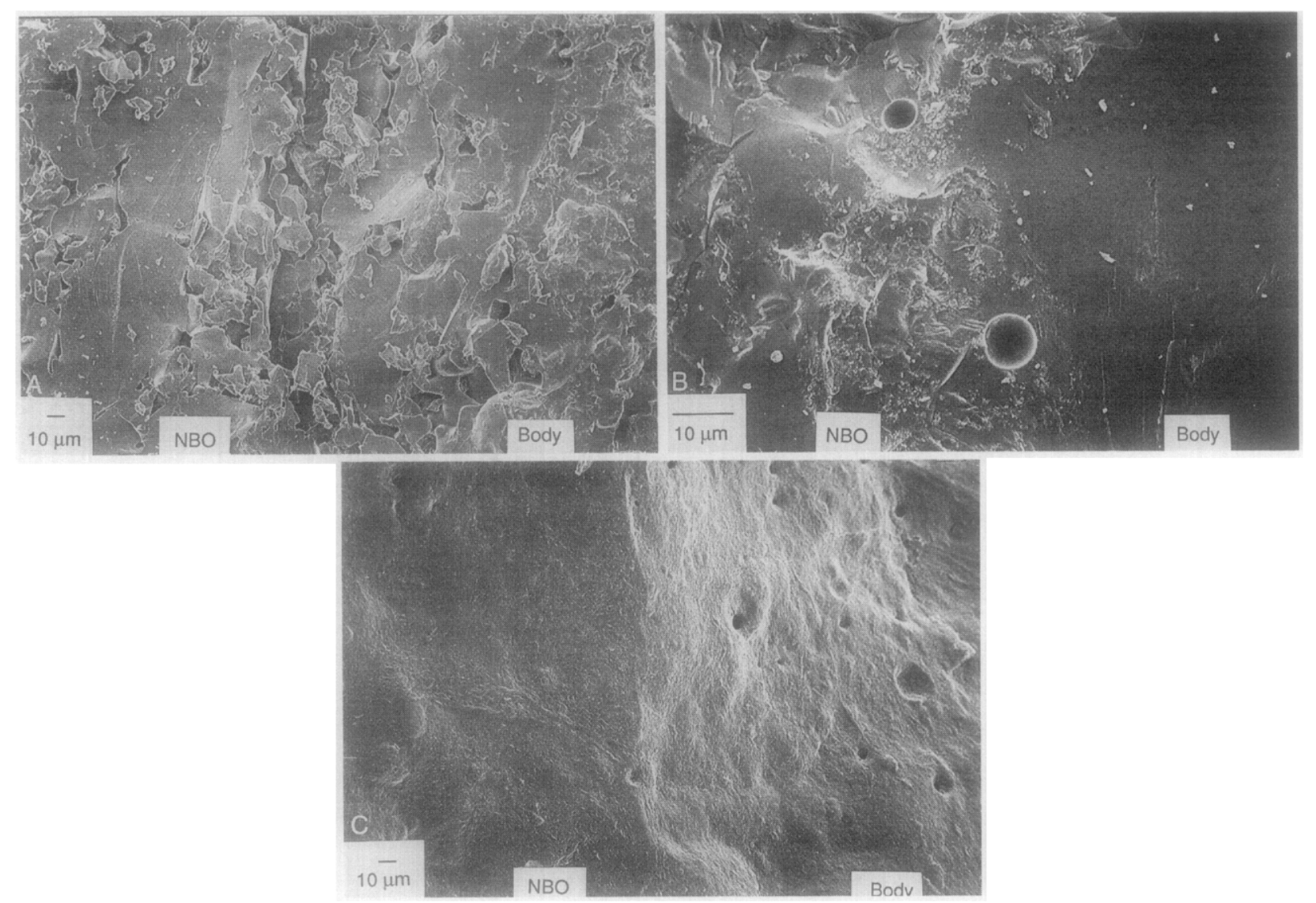

Fig. 3. SWM photomicrographs of No-Bake Opaque (NBO)/body porcelain intertace pro. duced by firing at (A) $1560^{\circ} \mathrm{F}\left(849^{\circ} \mathrm{C}\right),(\mathrm{B}) 1660^{\circ} \mathrm{F}\left(904^{\circ} \mathrm{C}\right)$, and (C) $1760^{\circ} \mathrm{F}\left(960^{\circ} \mathrm{C}\right)$.

Will-Ceram Wi and Jelenko Olympia alloys are shown in Fig. 4. It appeared that the bonding failure was mostly cohesive within the porcelain as evidenced by the porosity that is typical of these porcelains. Also, smaller areas of failure may exist within the porcelain-metal oxide diffusion zone or within the metal oxide as evidenced by the smoother regions at some locations along the periphery.

\section{Coeffcient of thermal expansion}

The coefficient of thermal expansion was $13.3 \pm$ $0.2 \times 10^{-6} /{ }^{\circ} \mathrm{C}$ (between $25^{\circ}$ and $500^{\circ} \mathrm{C}$ ) for No-Bake Opaque porcelain and $13.6 \pm 0.2 \times 10^{-6} /{ }^{\circ} \mathrm{C}$ (between $25^{\circ}$ and $500^{\circ} \mathrm{C}$ ) for the body porcelain. Student's $t$-test showed that no significant difference existed between these two porcelains ( $t$ statistic $-1.667, p 0.147$ ).

\section{Particle size analysis}

A particle size analysis found that $33.5 \%$ by weight of No-Bake Opaque particles were under $5 \mu \mathrm{m}$, compared with $20.6 \%$ by weight for the conventional opaque. NoBake Opaque porcelain also had a small percentage of particles over $50 \mu \mathrm{m}$, which was not found with the conventional opaque porcelain (Table III). Fig. 5 shows the particle size distribution of No-Bake Opaque and Brush-
Table III. Particle size anaysis of No Bare Opaque and Brush-O-Paque porcelains

\begin{tabular}{|c|c|c|}
\hline \multirow{2}{*}{$\begin{array}{l}\text { Euqualent } \\
\text { spherieal } \\
\text { diameter }\end{array}$} & \multicolumn{2}{|c|}{ Cummolstinge mess $(4)$} \\
\hline & No-Bake Opaque & 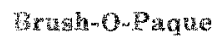 \\
\hline$<5 \mu \mathrm{m}$ & 33.5 & 20,6 \\
\hline$<10 \mu \mathrm{m}$ & 49.5 & 38.2 \\
\hline$<15 \mathrm{~mm}$ & 57.0 & 405 \\
\hline$<20 \mu \mathrm{m}$ & 63.1 & 600 \\
\hline$<25 \mu \mathrm{m}$ & 68.2 & 60.5 \\
\hline$<30, \mathrm{~mm}$ & 74.5 & 77.0 \\
\hline$<35 \mu \mathrm{m}$ & 78.5 & 84.2 \\
\hline$<40 \mu \mathrm{m}$ & $83 . \tilde{0}$ & 91.2 \\
\hline$<45 k \mathrm{~m}$ & 88.0 & 96.5 \\
\hline$<50 \mu \mathrm{m}$ & 91.5 & 1000 \\
\hline$<65 \mu \mathrm{m}$ & 94.5 & 100.0 \\
\hline$<60 \mu \mathrm{m}$ & 96.2 & 100.0 \\
\hline$<65 \mu \mathrm{m}$ & 97.5 & 100,0 \\
\hline$<70 \mathrm{~km}$ & 98.4 & 100.9 \\
\hline
\end{tabular}

O-Paque porcelains. These distributions were significantly different according to the Kolmogorov-Smirnov two-sample two-tailed test (maximum difference $0.329, p 0.05$ ). 

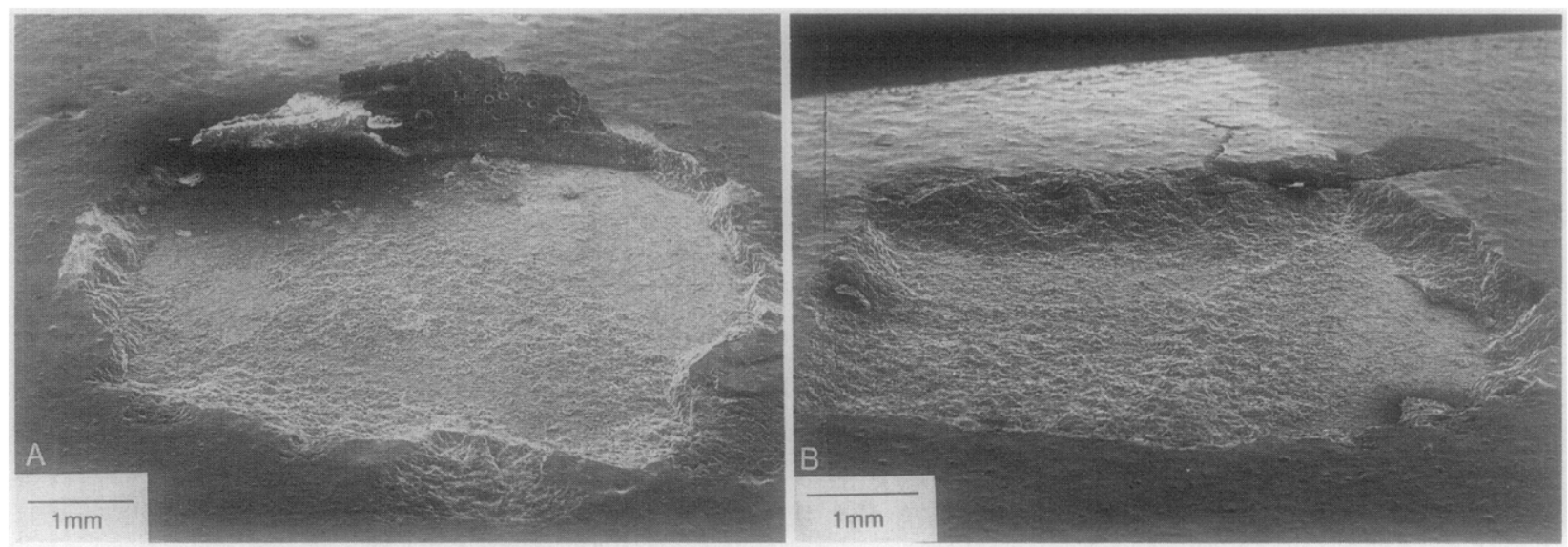

Fig. 4. SEM photomicrographs of No-Bake Opaque alloy fracture interface showing cohesive failure for (A) Will-Ceram W1 and (B) Jelenko Olympia alloys. Bonding failure was mostly cohesive within porcelain as evidenced by porosity that is typical of these porcelains. Smaller areas of failure may exist within porcelain-metal oxide diffusion zone or within metal oxide as evidenced by smoother regions at some locations along periphery.

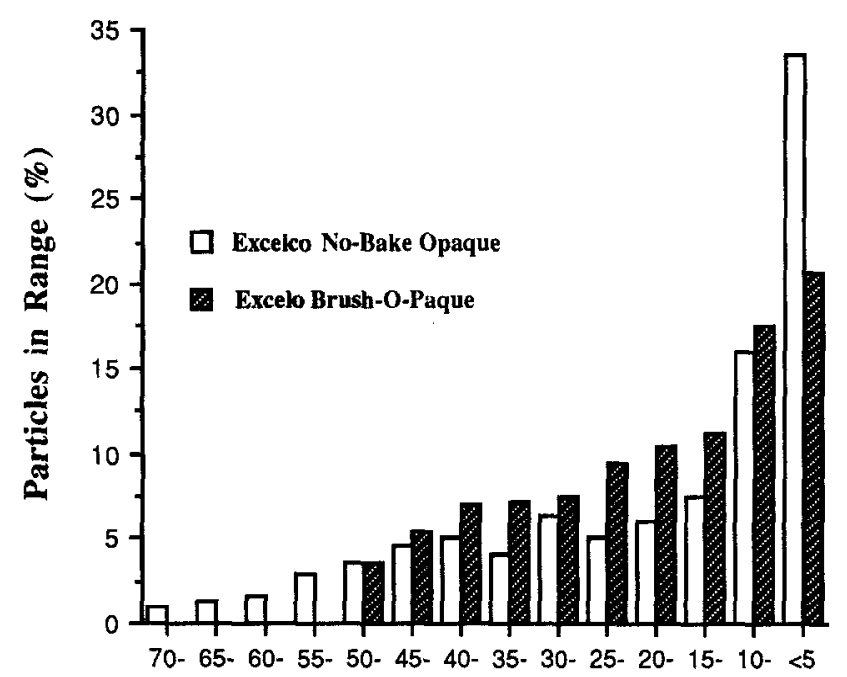

Equivalent Spherical Diameter $(\mu \mathrm{m})$

Fig. 5. Particle size distribution of No-Bake Opaque and Brush-O-Paque porcelains.

\section{DISCUSSION}

An opaque porcelain is used in metal-ceramic restorations to mask the color of the alloy, to provide the basis for the internal color of the restoration, and to bond the metal and the porcelain. ${ }^{3}$ Usually two thin applications of opaque porcelain are recommended. ${ }^{4-6}$ The No-Bake Opaque porcelain does not require a separate firing before application of the body porcelain. Therefore, it would save the dental technician the time required for the two opaque firing cycles and for the application of the second opaque layer during the preparation of a porcelain-fused-to-metal restoration.
The flexural strength of No-Bake Opaque porcelain was not statistically different when compared with that of a conventional opaque porcelain and was well above the ISO requirement ${ }^{1}$ of $55 \mathrm{MPa}$. This opaque porcelain appeared to be fully sintered at $1760^{\circ} \mathrm{F}\left(960^{\circ} \mathrm{C}\right)$, and the linear firing shrinkage was well within the ISO limit ${ }^{1}$ of $16 \%$ max. Photomicrographs showed that the bonding of the NoBake Opaque porcelain to the body porcelain was complete when fired at $1760^{\circ} \mathrm{F}\left(960^{\circ} \mathrm{C}\right)$. Bonding of this opaque porcelain to a palladium-silver alloy and a gold-palladium (silver-free) alloy was adequate as indicated by the cohesive failure of the opaque when examined by SEM. No significant difference occurred between the coefficient of thermal expansion for this opaque porcelain and the body porcelain manufactured to be used with it. A particle size analysis found $33.5 \%$ less than $5 \mu \mathrm{m}$ and $3.8 \%$ greater than $50 \mu \mathrm{m}$ for the opaque porcelain evaluated in this study. Opaque porcelains should consist of particles of several different sizes. ${ }^{3}$ A fine grain and variation in grain size of the porcelain powder will improve packing, giving the material a high green or wet strength, will reduce shrinkage, and will have an effect on sintering rates ${ }^{6,7}$ because smaller particles undergo fusion more rapidly. ${ }^{8}$

Additional studies on its performance in general production would be useful.

\section{SUMMARY}

Simultaneous firing of this special opaque porcelain and body porcelain produced satisfactory sintering, strength, and bonding to metal. The linear firing shrinkage and the flexural strength of this porcelain were well within the ISO requirements for dental ceramics. ${ }^{1}$

We thank Excelco International Inc. for their donation of the material used in this study. 


\section{REFIRENCES}

1. International Organization for Standardization. Dental ceramics. Ref No. $1506872-1984$ (E). Geneva, Switzerland: International Organization for Standardization, 1984.

2. O'Brien WJ. Dental porcelains. In: Craig RG, ed. Dental materials review. Ann Arbor, Mich.: University of Michigan Press, 1977:123-35.

3. Kuwata $\mathrm{M}$. Theory and practice for ceramo metal restorations. Chicago: Guintessence Publ Co, 1980:30-63.

4. Stein RS, Kuwata M. A dentisi and a dental technologist analyze current ceram-onetal procedures. Dent Clin North Am 1977;21:729-49.

5. McLean. JW. The science and art of dental ceramics. Vol 2. Bridge design and laboratory procedures in dental ceramics. Chicago: Quintessence Publ Co, $1980: 50,245$.
6. Johnston JP, Mumford G, Dykema RW. Wodem praction in dental aeramics. Philadelphia: WB Saunders, 1967:109, 188

7. Binns D. The chemical and physical properties at dental porcelain. In:

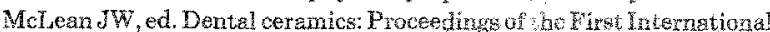
Symposium on Ceramios. Chicago: Ounintessence vabl Co, 1983:41-82.

8. Jones DW, Wilson HJ. Porosity in dental wramics br Dent d $1975 ; 138: 16 \div 21$

Reprint requests to:

Dr. William J. O'Brian

2203 SCYOOL OF DENTSSTRY

THW UNHERSTTY OF MKHEGAN

ANN ARBOR, MI 4B.109-1078

\section{Bound volumes available to subscribers}

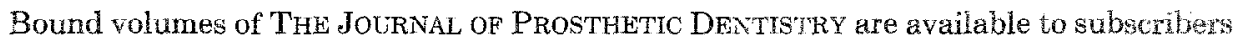
(only) for the 1994 issues from the publisher at a cost of $\$ 67.00$ ( $\$ 80.00$ intemational) for Vol. 71 (January-June) and Vol. 72 (July-December). Shipping charges are included. Fach bound volume contains a subject and author index, and all advertising is removed. Copies are shipped within 30 days after publication of the last issue in the volume. The bincing is durable buckram with the journal name, volume number, and year stamped in gold on the spine. Volumes 69 and 70 are also available. Payment must accompany all orders. Contact Mosby-Year Book, Inc., Subscription Services, 11830 Westine Industrial Drive. St. Louis, MO 63146-3318, USA; phone (800)453-4351, or (314)453-4851.

Subscriptions must be in force to qualify. Bound volumes are not avaluble in place of a regular JourNaI, subscription. 